\title{
INCREASED DURABILITY OF CONCRETE AGAINST HIGH TEMPERATURES DUE TO FIRE WITH GROUND GRANULATED BLAST FURNACE SLAG
}

\author{
A H S Harahap ${ }^{1}$, Sumargo ${ }^{2}$ and Nursyafril ${ }^{3}$ \\ ${ }^{1}$ Civil Engineering, Politeknik Negeri Bandung, Jalan Gegerkalong Hilir, Kec. Parongpong, Jawa Barat 40559 \\ E-mail : ahmadharahap298@ymail.com \\ ${ }^{2}$ Civil Engineering, Universitas Jenderal Achmad Yani, Jalan Terusan Jend. Sudirman, Kec. Cimahi Selatan, Jawa Barat 40531 \\ E-mail : sumargo@lecture.unjani.ac.id \\ ${ }^{3}$ Civil Engineering, Politeknik Negeri Bandung, Jalan Gegerkalong Hilir, Kec. Parongpong, Jawa Barat 40559 \\ E-mail : nursyafrilanwar@yahoo.com
}

\begin{abstract}
This paper describes experimental results that focus on impacts of elevated temperature on concrete with GGBFS. GGBFS from waste of steel factory PT Krakatau Steel Tbk. has been discovered to be appropriate for geopolymer cement as substitute for cement in concrete. Normal concrete and GGBFS concrete beams $(150 \times 150 \times 750 \mathrm{~mm})$ and cylindrical $(150 \times 300 \mathrm{~mm})$ with $40 \%$ GGBFS content as substitute of cement weight were burned for two hours, which the first beam was burned at $600^{\circ} \mathrm{C}$, second beam at $700^{\circ} \mathrm{C}$ and third beam at $800^{\circ} \mathrm{C}$. After cooling to room temperature, cylindrical and beams were tested. Compressive strength, modulus of elasticity and flexural strength were examined and compared. The results show that GGBFS increased durability of concrete and might be utilized in applications including elevated temperatures. High temperature exposure causes compressive strength of normal concrete decreased extremely up to $69.08 \%$, compared to GGBFS concrete only $46.21 \%$. Flexural strength decreased to $30.37 \%$ when the temperature rises to $700^{\circ} \mathrm{C}$. Furthermore, it decreased significantly to $50.82 \%$ when the temperature reached $800^{\circ} \mathrm{C}$.
\end{abstract}

Keywords: Concrete; Durability; GGBFS; Temperatures.

\section{INTRODUCTION}

Fire is one of the causes of failure of concrete construction structures, which could happen withinside the area of the bridge. Concrete exposed to fire, and it cause the concrete structure to have into extreme high temperature changes. Although concrete is resistant to fire, its physical and mechanical properties degenerate if exposed to high temperatures [9]. The fire of merchant stalls under the Ampera bridge on 10 October 2010 and a ship on fire below the Ampera Bridge on 20 December 2018 triggered a temperature rise at the girder beam.

Effect of exposure to high temperatures are decreasing the durability, mass loss, degradation of compressive strength, flexural strength, modulus of elasticity and cracks [3]. Extent of damage caused by a fire disaster could be caused by duration and temperature of fire, which is the percentage of concrete compressive loss to $60 \%$ [2].

Besides using refractory cement, which is quite expensive, GGBFS from waste of steel factory PT Krakatau Steel Tbk. has been observed to be appropriate for geopolymer cement as substitute for cement in concrete, to reduce such as spalling on concrete surfaces and cracks in concrete because of high temperatures from fires. The forming detail of GGBFS are lime, silica, and alumina, that have cementitious matrix like cement [10]. Concrete containing up to 50\% GGBFS as substitute for cement in concrete are taken into consideration appropriate for using constructing systems, roads, and bridges [1]. Siddique and Kaur studied the mechanical matrix of GGBFS concrete exposed to temperatures of 100,200 and $350^{\circ} \mathrm{C}$, the result is no significant damage at $100^{\circ} \mathrm{C}$. At $200^{\circ} \mathrm{C}$ the loss of mass that occurs is not significant. Reduction of compressive and tensile strength and modulus of elasticity less than $40 \%$ occurs at $350^{\circ} \mathrm{C}$ [6].

In this study, normal and GGBFS concrete were fabricated and tested before and after three diverse temperature exposures which were $600^{\circ} \mathrm{C}, 700^{\circ} \mathrm{C}$ and $800^{\circ} \mathrm{C}$. The beams specimen was tested by a two-point flexural load, then the midspan deflection and load capacity were examined and compared. Then cylindrical specimens were tested by its compressive strength and modulus of elasticity.

The results of this study are in the form optimization of the use of GGBFS on concrete in girder beams to produce girder beam with GGBFS concrete by following the good quality and better durability toward increase high temperatures due to fires than normal concrete. Concrete that uses GGBFS as a substitution of the weight of the cement will reduce the use of cement so that construction costs, especially in concrete will be reduced without having to reduce the quality of concrete. The experimental data presented may assist in the application of GGBFS concrete to the sustainable development of infrastructure construction. 


\section{METHODS}

In this experimental method, mix design method for concrete is ACI 211.1-91, ordinary Portland cement used for this, and concrete quality is $30 \mathrm{MPa}$. Began with compressive strength of concrete to determine the optimum levels of GGBFS mixture in concrete mixes. The highest of compressive strength values will be used as the optimum GGBFS mixture level in the mix design of the next test specimen. Specimens with optimum levels of GGBFS were fabricated and tested, then mechanical and physical properties were examined before and after combustion. The specimens were split into two groups, namely normal concrete (NC) and GGBFS concrete (GC). Details of the specimen could be seen below.

Table 1. Detail of specimens.

\begin{tabular}{|c|c|c|c|c|c|c|c|c|c|}
\hline \multirow[t]{2}{*}{$\begin{array}{l}\text { Dimension } \\
\quad(\mathrm{cm})\end{array}$} & \multicolumn{3}{|c|}{$\begin{array}{l}\text { Unburned } \\
\text { Specimen }\end{array}$} & \multicolumn{6}{|c|}{ Burned Specimen } \\
\hline & & $\mathrm{NC}$ & $\mathrm{GC}$ & $\mathrm{NC}$ & $\mathrm{GC}$ & $\mathrm{NC}$ & $\mathrm{GC}$ & $\mathrm{NC}$ & $\mathrm{GC}$ \\
\hline Cylinder (Ø15×30) & Sample ID & C-UNC & C-UGC & $\mathrm{C}-\mathrm{NC} 600^{\circ} \mathrm{C}$ & $\mathrm{C}-\mathrm{GC} 600^{\circ} \mathrm{C}$ & $\mathrm{C}-\mathrm{NC} 700^{\circ} \mathrm{C}$ & $\mathrm{C}-\mathrm{GC} 700^{\circ} \mathrm{C}$ & $\mathrm{C}-\mathrm{NC} 800^{\circ} \mathrm{C}$ & $\mathrm{C}-\mathrm{GC} 80^{\circ} \mathrm{C}$ \\
\hline Beam $(15 \times 15 \times 75)$ & Sample ID & B-UNC & B-UGC & $\mathrm{B}-\mathrm{NC} 600^{\circ} \mathrm{C}$ & $\mathrm{B}-\mathrm{GC} 600^{\circ} \mathrm{C}$ & $\mathrm{B}-\mathrm{NC} 700^{\circ} \mathrm{C}$ & $\mathrm{B}-\mathrm{GC} 700^{\circ} \mathrm{C}$ & $\mathrm{B}-\mathrm{NC} 800^{\circ} \mathrm{C}$ & $\mathrm{B}-\mathrm{GC} 800^{\circ} \mathrm{C}$ \\
\hline
\end{tabular}

In Table 2, each cylindrical specimen must be weighed before and after combustion. Modulus of elasticity and compressive strength of the concrete before and after combustion were obtained from the test on cylindrical specimens. Meanwhile, beams were tested for flexural strength. Compressive strength tests of concrete refer to SNI 03-6429-2000 and flexural strength to SNI 4431: 2011 with two-point loading system. Scheme of flexural test could be seen below.

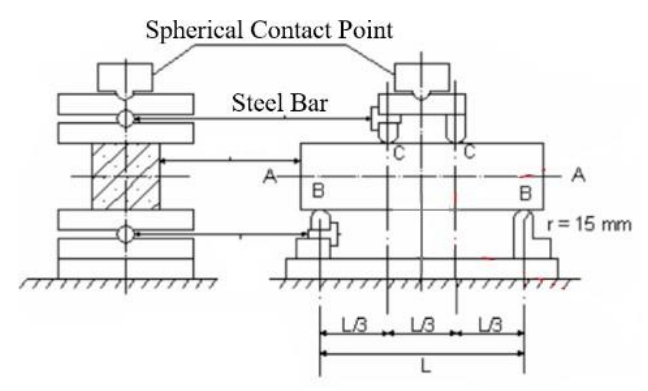

Figure 1. Scheme of flexural strength testing.

Combustion process in this research refers to the standards of the ASTM E119-2000. The combustion is carried out at room temperature $\left(27^{\circ} \mathrm{C}\right)$ by placing the test object in the combustion furnace, then combustion begins until it reaches the target temperature, where the time required to reach the target combustion temperature lasts for \pm 30 minutes. The targeted temperatures are $600^{\circ} \mathrm{C}, 700^{\circ} \mathrm{C}$ and $800^{\circ} \mathrm{C}$ then when the temperature reaches the target, the temperature is maintained for 120 minutes. After that, the combustion process is stopped and allowed to reach room temperature.

\section{RESULT AND DISCUSSION}

Test the samples for optimal GGBFS values. The test results are shown in Figure 2.

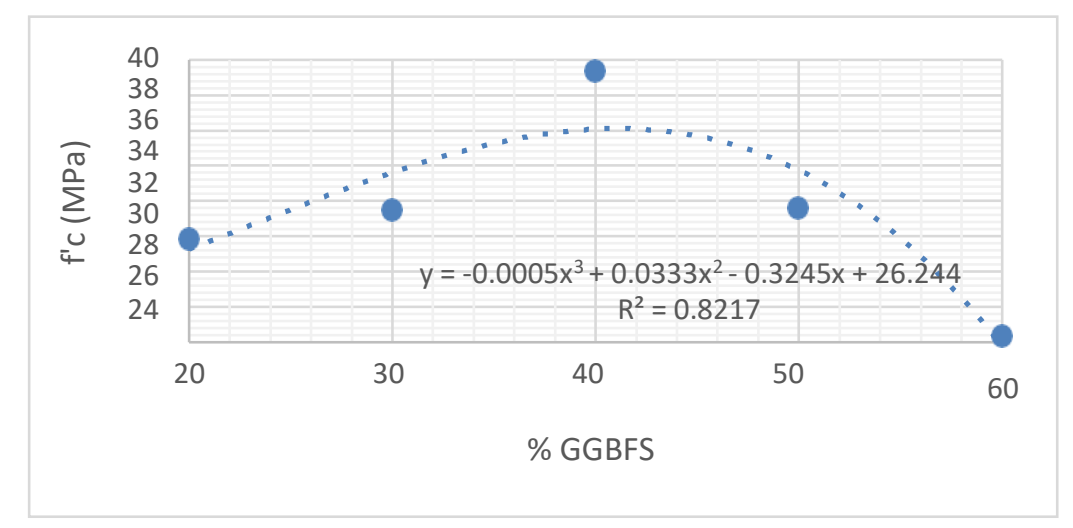

Figure 2. Compressive strength of GGBFS concrete. 
In Figure 2, the optimal amount of GGBFS as a substitute of cement at 40\% with an average compressive strength is 39,33 MPa, compared to $30 \%$ and $50 \%$, compressive strength increased to $31,46 \mathrm{MPa}$ and $31,57 \mathrm{MPa}$, respectively. This is just a minor increase of the strength due to the compressive strength design $(30 \mathrm{MPa})$, and $60 \%$ of the GGBFS of the total cement weight cause compressive strength decreased to $24.31 \mathrm{MPa}$, so the optimal level of GGBFS to replace cement is $40 \%$.

Specimens with $40 \%$ GGBFS as a substitution of cement weight were fabricated as GGBFS concrete (GC). Burned and unburned cylinder specimens of NC and GC were tested for modulus of elasticity and compressive strength. Results of burned and unburned compressive strength specimens can be seen in Figure 3.

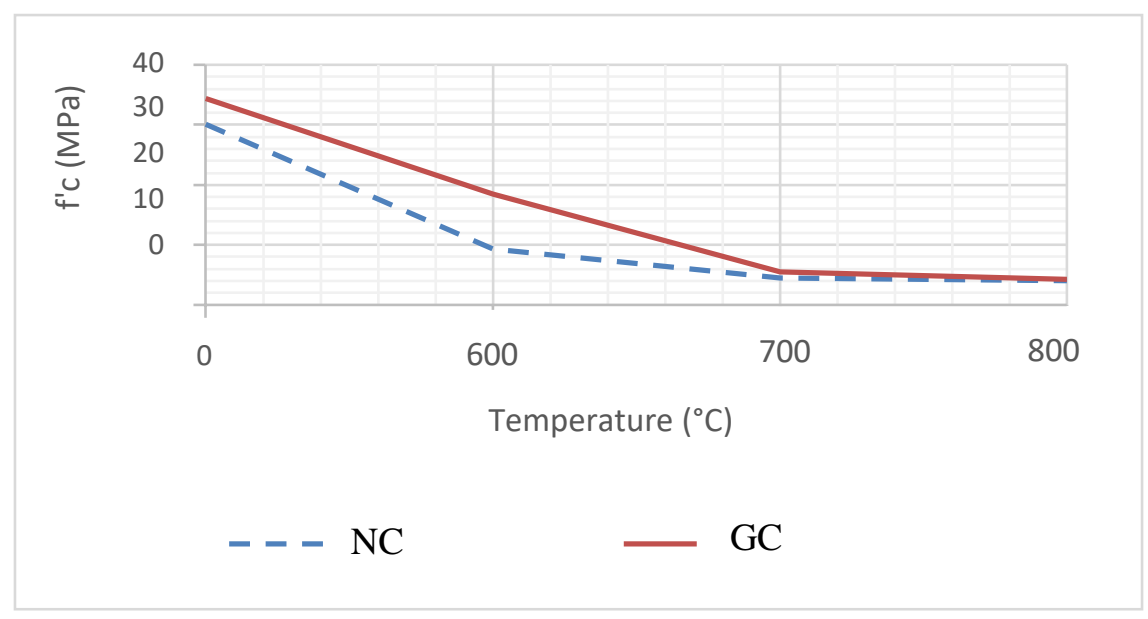

Figure 3. Impact of temperature on compressive strength

Graph from Figure 3 shows the information that the concrete strength decreased significantly after exposure of elevated temperature. As the temperature elevated to $600^{\circ} \mathrm{C}$, reduction at compressive strength of NC specimens was $69.08 \%$ while GC was $46.21 \%$. This shows that GGBFS increases concrete strength, in which GC compressive strength of $34.38 \mathrm{MPa}$ is greater than NC's of $30.06 \mathrm{MPa}$ and GGBFS reduces the impact of loss of strength due to exposure to high temperatures. Compressive strength decreased dramatically when the temperature reached $600^{\circ} \mathrm{C}$ and $\mathrm{GC}$ still greater than $\mathrm{NC}$. From $600^{\circ} \mathrm{C}$ up to $800^{\circ} \mathrm{C}$, reduction of compressive strength of GC and $\mathrm{NC}$ was significantly greater with a slightly different compressive strength value.

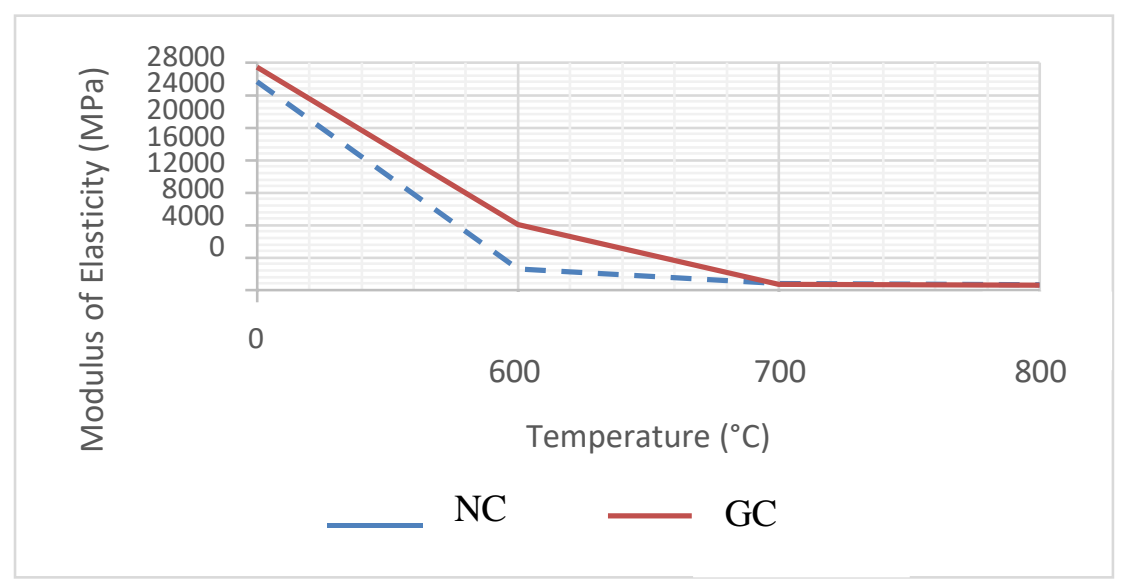

Figure 4. Impact of elevated temperature on modulus of elasticity

Graph of Figure 4 shows modulus of elasticity of the concrete after exposure has decreased with increasing temperature. Moreover, impact of temperature increase to GC specimens shows that the application of GGBFS causes reinforcement to the specimens and reduces the impact of decreasing strength, compared to NC specimens. For unburned GC, the modulus of elasticity is $27455.6 \mathrm{MPa}$. The modulus of elasticity in GC is greater, compared to NC which is $15550.6 \mathrm{MPa}$. The reduction of modulus of elasticity in $\mathrm{GC}$ after exposed to $600^{\circ} \mathrm{C}, 700^{\circ} \mathrm{C}$ and $800^{\circ} \mathrm{C}$ were $70.48 \%, 97.57 \%, 97.85 \%$, respectively, while NC's were $89.81 \%, 96.88 \%, 97.47 \%$, respectively. It can be seen from the graph above, elevating temperature of up to $600^{\circ} \mathrm{C}$, modulus of elasticity of GGBFS concrete was greater than NC, but it gradually decreased when the temperature increased up to $800^{\circ} \mathrm{C}$. 


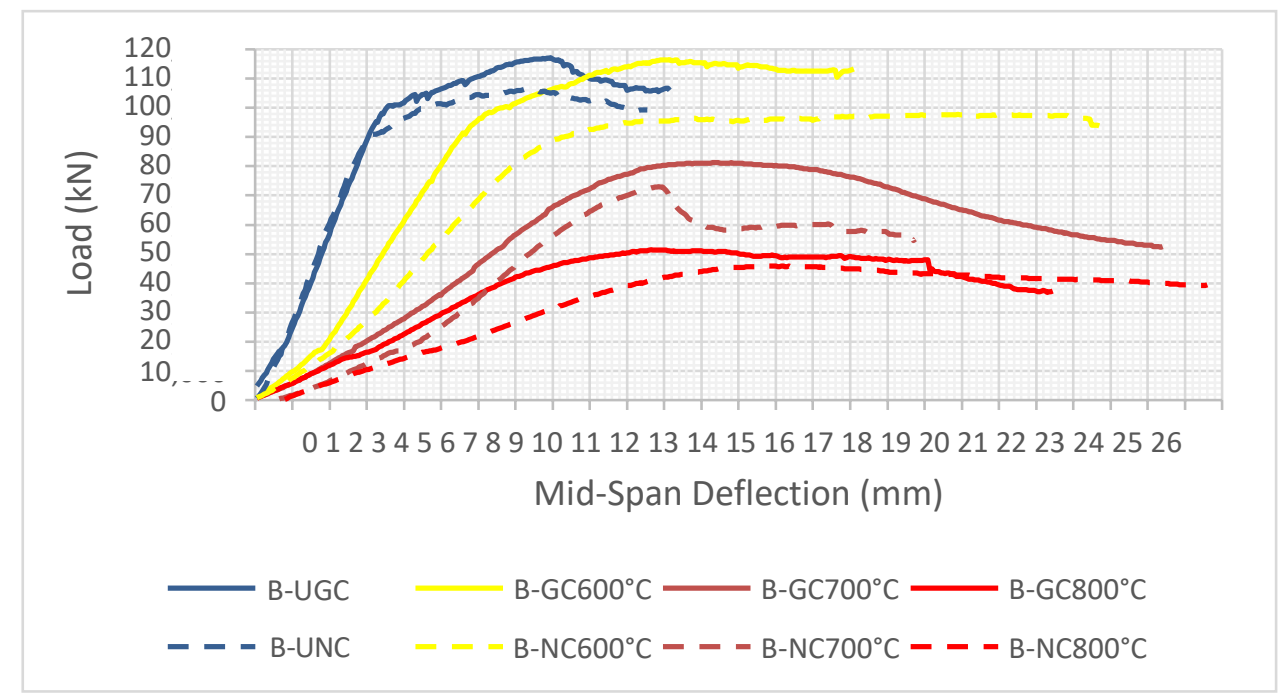

Figure 5. Flexural strength of GGBFS and normal concrete toward elevated temperature

As shown in Figure 5, the curves of B-UGC correspond approximately to that B-UNC, but B-UGC demonstrating a higher capacity in peak load $117.041 \mathrm{kN}$ than B-UNC $106.490 \mathrm{kN}$. Each GC and NC gained a gradual reduction in flexural strength upon thermal exposure. It insignificantly decreases in flexural strength in the specimens at the temperature of $600^{\circ} \mathrm{C}$, where $\mathrm{GC}$ decreased by $0.44 \%$ and $\mathrm{NC}$ at $8.14 \%$. The strength in GC and BC decreases drastically with an average value of $30.79 \%$ at $700^{\circ} \mathrm{C}$, and increase $56.38 \%$ at temperatures up to $800^{\circ} \mathrm{C}$. In comparison, the curves of the NC samples are below the curves of the GC, indicating that the GGBFS increases the strength of the concrete. In addition, GGBFS increases the flexural rigidity of GC samples compared to NC samples, even after exposure to elevated temperatures.

\section{CONCLUSION}

Modulus of elasticity and compressive strength of concrete between GGBFS and normal concrete were analyzed and compared before and after burning at three different temperatures. It could be concluded that modulus of elasticity and compressive strength decrease significantly at high temperatures. In addition, this also affects the specimen of the beam, where the initial crack and maximum load values of the flexural strength test results decrease with increasing temperature.

The results indicate if addition of GGBFS to the concrete mixture cause compressive strength increased and loss relatively little strength when the concrete is exposed to elevated temperatures. Compressive strength of GGBFS concrete examined in this test is greater, then the concrete will experience less strength loss due to high temperature exposure up to $600^{\circ} \mathrm{C}$ than normal concrete with lower original compressive strength. When the increased temperature reaches $600^{\circ} \mathrm{C}$, the compressive strength of normal and GGBFS concrete decreases dramatically, where the strength loss is more than $50 \%$. On the other hand, when GC and NC specimens are exposed to temperatures more than $600^{\circ} \mathrm{C}$ to $800^{\circ} \mathrm{C}$, the loss of strength that occurs in both is almost the same. However, flexural strength and compressive strength of GGBFS concrete are greater than normal concrete.

\section{ACKNOWLEDGMENT}

This opportunity to thank all faculty staff in the Civil Engineering Department of Politeknik Negeri Bandung for the support and always giving a hand. We also thank to PT Krakatau Semen Indonesia for the Ground Granulated Blast Furnace Slag so that this research could be goes well and finish on time. 


\section{REFERENCES}

[1] Qingtao L, Zhuguo L and Guanglin Y 2012 Effects of elevated temperatures on properties of concrete containing ground granulated blast furnace slag as cementitious material Construction and Building Materials, 687-688.

[2] Isa Y, Rafat S and Omer O 2011 Influence of high temperature on the properties of concretes made with industrial byproducts as fine aggregate replacement Construction and Building Materials 25 967-972

[3] Qianmin M, Rongxin G, Zhinman Z, Zhiwei L and Kecheng H 2015 Mechanical Properties of Concrete at High Temperature Elsevier 93371 - 383

[4] Junru R, Huiguo C, Tao S, Hao S and Miaoshuo W 2017 Flexural Behaviour of Combined FA/GGBFS Geopolymer Concrete Beams after Exposure to Elevated Temperatures Advances in Materials Science and Engineering, 1-9

[5] Imene S and Abdelaziz B 2016 Behaviour of high-strength concrete incorporating ground granulated blast furnace slag at high-temperature Rev. Sci. Technol Synthèse 33106 - 116, 33, 106 - 116.

[6] Rafat S and Deepinder K 2011 Properties of concrete containing ground granulated blast furnace slag (GGBFS) at elevated temperatures Journal of Advanced 3 45-51

[7] Carbera M, Escalante G and Castro B 2016 Compressive strength of concretes with blast furnace slag. Re-visited state-ofthe-art Journal of the Latin-American Association of Quality Control, Pathology and Recovery of Construction 6 64-83

[8] Beddar M 2013 Reactivity of Granulated Blast Furnace Slag Slovak Journal of Civil Engineering 21 7-14

[9] L T Phan, J R Lawson and F. L. Davis 2001 Effects of elevated temperature exposure on heating characteristics, spalling, and residual properties of high-performance concrete Materials and Structures 34 83-91

[10] Erdogan O, Mustafa E and Halil I D 2016 Utilization and efficiency of ground granulated blast furnace slag on concrete properties $-A$ review Construction and Building Materials 105 423- 434 